This item was submitted to Loughborough's Research Repository by the author.

Items in Figshare are protected by copyright, with all rights reserved, unless otherwise indicated.

\title{
Book review: Visual political communication
}

PLEASE CITE THE PUBLISHED VERSION

https://doi.org/10.1177/1940161220942693

\section{PUBLISHER}

SAGE Publications

\section{VERSION}

AM (Accepted Manuscript)

\section{PUBLISHER STATEMENT}

This paper was accepted for publication in the journal The International Journal of Press/Politics and the definitive published version is available at https://doi.org/10.1177/1940161220942693. Users who receive access to an article through a repository are reminded that the article is protected by copyright and reuse is restricted to non-commercial and no derivative uses. Users may also download and save a local copy of an article accessed in an institutional repository for the user's personal reference.

\section{LICENCE}

CC BY-NC-ND 4.0

\section{REPOSITORY RECORD}

Stanyer, James. 2020. "Book Review: Visual Political Communication”. Loughborough University. https://hdl.handle.net/2134/13691101.v1. 
The International Journal of Press/Politics 26(1) 302-304

Visual Political Communication. Palgrave Macmillan, 2019, 288pp

978-3-030-18729-3 eb

978-3-030-18728-6 pb

Anastasia Veneti; Daniel Jackson; and Darren G Lilleker

James Stanyer, Loughborough University

The call for researchers to pay more attention to visuals in the study political communication is not new (for a synoptic account see Barnhurst and Quinn, 2012), but the examination of visuals remains underdeveloped, especially when compared to the focus on texts, for example. Indeed, the editors' of this book note there have been few works that focus 'on the various ramifications of the visual in political communication' (Lilleker et al., 2019, p.6). This edited collection joins previous attempts draw our attention to the analysis of images (see for example, Grabe and Bucy's work on image bites) but it is especially timely because of the growth and almost ubiquitous use of social media which, as the editors' note, 'have created novel ways of producing, disseminating and consuming visual products' (Lilleker et al., 2019, p.5). This volume provides 'a theoretically driven empirically grounded survey of the central role of visual communication plays in political culture' in contemporary democracies (Lilleker et al., 2019, p.5), with the goal of invigorating the study of visuals in political communication. The volume examines the theory and methods that underpin the study of visuals as well as providing a series of substantive case studies, which look at the activities of established political communicators in the context of campaigns and governance, and the use of 'visuals from below' by civil society actors outside the political establishment. The collection is organised into four parts.

Part one examines the theoretical and methodological issues involved in researching visuals. It sets out the 'basis for understanding the role of visuals within political communication' (Lilleker et al., 2019, p.6). The opening substantive chapter by Messaris, places the study of visuals in political communication within a historical context of the development of new technologies, focusing on three technological developments. In Lilleker's chapter the focus shifts to the impact of visuals. Lilleker explores the positive and negative power of visuals in attitude formation. Visuals offer a cognitive short cut to support decision making but also simplistic thinking which can lead to cognitive mistakes. The chapter by Geordimos puts the study of visual political communication in a wider methodological context of visual research methods. He argues visual analysis has a long way to go and sets out an imaginative research agenda to progress the studies of visuals. Pauwels' chapter also examines visual research methods. It provides a comprehensive overview of 
methods for analysing the 'visual dimensions of political phenomena' it explores the various 'methods, techniques and technologies' (Pauwels, 2019, p. 92) available to analyse political communication.

The focus of the second section is on a series of empirical studies. Johansson and Holtz-Bacha's illuminating study explores visual negativity in election posters in Germany and Sweden, finding it has increased overtime in both countries. The chapter by Russmann et al., explores the meaning and iconography of politicians Instagram postings during Swedish and Norwegian elections. They suggest that Instagram impacts on the nature of campaign communication leading to more personalized messages to convey a sense of closeness during the campaign but also leads to an over simplification of party messages. The chapter by Novelli explores visual political communication in Italian election campaigns. He examines the transformation of campaign visuals across campaigns, focusing on Italians politicians, identifying trends towards increased importance of social media visuals in the self-promotion process. Visuals in these platforms tend to be simpler 'less sophisticated and elaborate' but 'no less effective' (Novelli, 2019, p. 160).

The third section examines the role of visuals in governance. The chapter by Strand and Schill examines Donald Trump's use of visuals in his first 100 days in office. It reveals how Trump used visuals on Facebook and Twitter to generate a positive impression of a leader in command as part of a strategy to legitimate his presidency, and allay criticisms of foreign interventions in the US presidential elections. In their chapter, Poulakidakos and Giannouli examine the visuals used by political leaders in Greece on Instagram. Despite some differences between party leaders, they tend to use Instagram to promote a positive image of themselves, it provides them with an opportunity to shape their public persona unfiltered by the media. Instagram affords them a new opportunity to project visuals which generate a positive impression of them and their activities. Suelflow and Maurer's chapter examines how visual cues exhibited by politicians in the media, such as facial expressions, impacts upon citizens in Germany, in particular, they are interested in the effects of smiling and whether it is especially influential, via a range of tracking technologies. The study finds more positive impressions were formed when politicians smiled, however, this was tempered by the audio that accompanied the visual sequences and whether they were in agreement with it.

The fourth section of the book focuses on civil society actors. Parry examines the role of visuals in acts of memorialization on social media by citizens, it explores the use of visuals in posts on the MorelnCommon Twitter hashtag, which was used as a platform to express sorrow after the murder of UK MP, Jo Cox, in 2016, and construct a common 'we'. The chapter by Blaagaard looks at iconic visuals in political and social contexts theorising about the power of grass roots civil rights campaign visuals in the digital era. It uses visual discursive analysis to examine modalities of protest visuals, looking at the case of Black Lives Matter movement and the role of visuals in promoting social and political change. In the last chapter 
Medrado et al., explore how protest visuals are used to build connections between media activists and gain attention but also how the algorithmic logics of digital environments, and the economic rationale of the environment, may work against the promotional strategies employed. The chapter explores the connections between Brazilian political movements and parties on YouTube and the different strategies used by these groups. Their desire to gain more visibility on the one hand is undermined by the YouTube's algorithmic logic which does not aid the access of material that aligns to their political preferences.

This collection is a welcome intervention that, in the editors' words, places visuals at the 'epicentre' of the relationship between political communicators and audiences. The various chapters draw our attention to a number of important developments, in particular the rise of social media and go someway to addressing what remains an 'under researched area' in political communication, providing a theoretical framework and methodological guidelines to aid future studies. I would recommend this collection to all those interested in understanding and analysing political visuals in contemporary democracies.

\section{References}

Barnhurst, K G. and Quinn, K. (2012) Political visions: Visual studies in political communication. In (Eds) The Sage Handbook of Political Communication. Thousand Oaks, CA. Sage.

Grabe, M E., and Bucy, E P. (2010) Image Bite Analysis of Political Visuals: Understanding the Visual Framing Process in Election News. In E P. Bucy, R. L Holbert (Eds) Sourcebook for Political Communication Research Methods, Measures, and Analytical Techniques. London: Routledge

Lilleker, D G., Veneti A., and Jackson, D. (2019) Introduction: Visual Political Communication. In A. Veneti, D. Jackson, and D G. Lilleker (Eds) Visual Political Communication. Basingstoke: Palgrave.

Novelli, E. (2019) Visual Political Communication in Italian Electoral Campaigns. In A. Veneti, D. Jackson, and D G. Lilleker (Eds) Visual Political Communication. Basingstoke: Palgrave.

Pauwels, L. (2019) Visual Methods for Political Communication Research: Modes and Affordances. In A. Veneti, D. Jackson, and D G. Lilleker (Eds) Visual Political Communication. Basingstoke: Palgrave. 